\title{
The Role of Women in Advocacy and Community Reform
}

\author{
${ }^{1}$ M. Khoirul Hadi al Asy'ari, ${ }^{2}$ Dwi Astuti Wahyu Nurhayati, ${ }^{3}$ Miftahus Sa'diyah \\ ${ }^{1}$ Shari'ah Department, Faculty of Shari'ah IAIN Tulungagung, Indonesia \\ ${ }^{2}$ English Education, Faculty of Tarbiyah and Teacher Training IAIN Tulungangung, Indonesia \\ ${ }^{3}$ Tarbiyah Faculty Arabic Language Education Study Program and Teacher Training Jember, Indonesia
}

\begin{abstract}
In advocacy, women need to be identified so that we can attribute a role to their level. The judgment of the thing is part of his conception, which makes the knowledge of women's reality a priority. When we follow the evolution of women's life long ago to this day, we find that it is doomed. The role of women in advocacy: First and before I go on the subject must understand what is the area of advocacy that we want women to do it? Yes, it is the whole society, because this role can only be achieved if the society is included, whose life revives the nation and dies. When he says: "Believers and believers, some parents of some enjoin the good and end the evil and believe in God," he means what he says, because the knowledge of Virtue and Prevention of Vice cannot be achieved only in the open society, which makes women contribute to the role of men. And the role of women in the reform of society, which is called the Holy Quran, which sees good and forbidding evil is no doubt and cannot be denied only Makbar. The gift of the Holy Prophet in social life is conclusive evidence that Muslim women were present alongside men and at all levels. Here I am compelled to shorten some of the evidence that shows the constant and continuous presence in the life of the Prophet and after him in the open ages, which represented the finest era throughout Islamic history.
\end{abstract}

Keywords: Women, Advocacy, Islam

\section{Research Background}

Often one is under societal pressure, imposing things that restrict his freedom somewhat. Our Eastern society is different from other societies. Let us take an example of society's pressure on women and their way of thinking: In the past, most of the role of women-a role in my opinion-was limited to the house and the raising of children. She is a princess in her home, trusted by her husband, who gives her his money and works hard to obtain it. But the man saw himself as the guardian, and sees in his wife weakness and strength together at the same time, her strength arising from carrying her home on her shoulders, and help her without burdening him, and weakness arising from her constant need for him. The situation has changed a lot, and the thinking of both men and women has changed differently. The gap has widened, the outlook has changed, and women see men as deprived of their freedom, even though, in the eyes of modern women, they won it a bit when they were liberated. And exercised many of the rights that she was deprived of. Nevertheless, she is still dissatisfied, while the man - in return - began to feel friendly in dealing with, and looked at her with a look of concern, distance, and interrelated conflicts, this by, And another aspect: a short look at the right $b$ Tha and right. 
The defense plan adopted by the authors on the subject of women, has improved them to mobilize the glories of women in all their ages as much as possible to access them, and the reluctance of what you find in some of these works of materials, cannot come out of a comprehensive idea about the correct work of Islam, How to save it, and where it is included, but you find in most of the general speech lacks health and support and witness.

\section{Women in Advocacy}

The call to God is not limited to men but women, but the call to God is directed to both men and women alike, and urged by the Koran and Sunnah purified. The Almighty says:

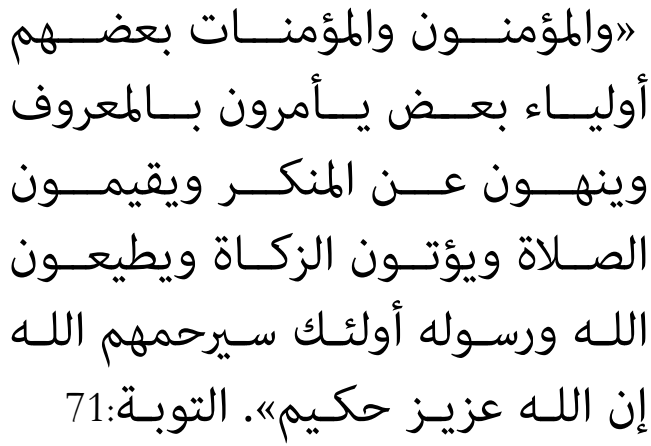

Says Almighty:

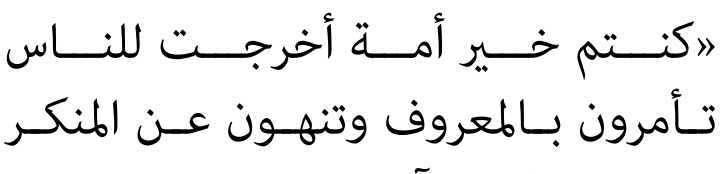
وتؤمنون باللهش. آل عمران:110،

And the wording of a nation in the verse includes men and women, and the Sunnah reported that the Prophet peace be upon him said: But women are the sisters of men. It is narrated by Ahmad and alTirmidhi and others, and when women bear the responsibility of calling to Allah, which is a great task, it has to be based on the values and teachings of Islam, and the foundation upon which to base it is the Book of Allah and the Sunnah of His Messenger. What you have stuck with them: the Book of God and the Year of His Prophet. AlMawtah, and the message Muhammadiyah has made since its inception calls to God, from the command of the wives of the Prophet to tell what is recited in their homes of verses and wisdom, which have the honor of hearing and knowledge without others. God says:

$$
\text { الأحزاب:34إذكمة إن الله كان لئل فيوتكن من آيات الله }
$$

Before talking about the role of women in advocacy, women need to be identified so that we can attribute a role to them in their level. The judgment of the thing is part of his conception, which makes the knowledge of women's reality a priority. When we follow the evolution of women's life long ago to this day, we find that it is doomed. With a one-sided look only owned by men and not shared by women. Yes, it is true to admit that there have been changes in women in general, according to cultures, customs and religions, but it is the man's shadow that determines women's duties and rights. And not long ago there is no sources of women written by the woman herself, and this complete absence of women from public life in relation to their rights and causes 
caused by the decline of its activity in the private area where the very activity does not exceed the family activity, hence the difficulty in obtaining sources Neutral in the history of women in general, because all that we have of these sources was written with a view dominated by the male mentality.

All that the historian has been many pictures that recognize women only add to others which diminishes it and gives it a fictional or metaphorical character often, which are pictures of the work the man's imagination is like the gods of Greece; Aphrodite, Athens, Dianne and many others. Or Jean d'Arc or Marianne, who are the statues of the Republic and the homeland in French culture. As well as with female figures in the Bible, such as Eve, Mary, and Mary Magdalene. They are often contrasting and contradictory figures, where they have historically attracted offerings, prayers, chastity, and disgust. This emotional contradiction in the perception of the gentile sex in Western Christian society is caused by the belief that women are the cause of human guilt on the one hand, and on the other hand, the view that women are the origin of life, represented by Mary.

It is difficult to give a definition of women, we are also Muslims because the view of men is still governed by the concept of masculinity, which is closer to the vision of ignorance, which came to change Islam as a false view historically. And even after he said the Holy Quran:

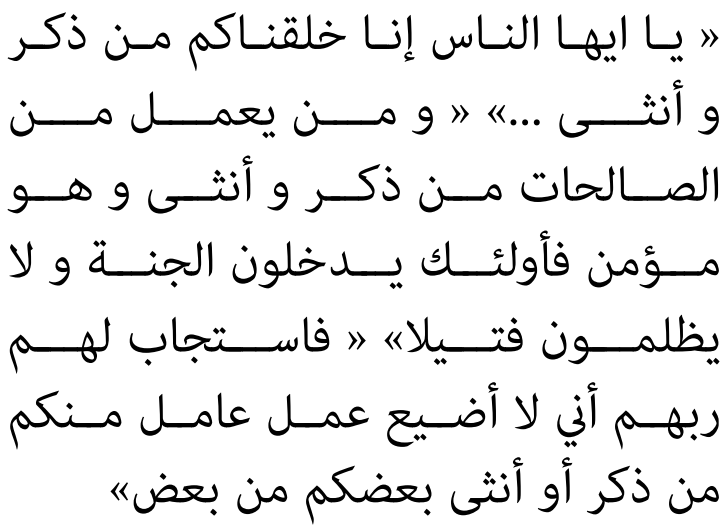

The Muslims still distinguish between men and women on the basis of masculinity and femininity, and this is definitely wrong view of the Holy Quran, the rule is good work and piety only.

All we can do is give a rough definition of women that emerges as an independent entity from tariff additives. Definition of women: It is that gentle object, which combines with men in the origin of the Creator and differs with him in the physiological structure. The God said: "و لـيس الـكر كـالأنثى that means in physiological construction and hence in tasks assigned to each.

The definition of the call to God: is to provide an integrated approach to life to Muslims and others happy in this world and the Hereafter. God said: "Say these, my ways, call to God on the insight of me and of those who follow me

$$
\begin{aligned}
& \text { «" إن الدين عند الله الإسلام" " و من } \\
& \text { يبتغي غير الإسلام دينا فلن يقبل منه و } \\
& \text { هو في الآخرة من الخاسرينب. إسين. }
\end{aligned}
$$

The role of women in advocacy: First and before I go on the subject must understand what is 
the area of advocacy that we want women to do it? Yes, it is the whole society, because this role can only be achieved if the society is included, whose life revives the nation and dies. When God says:

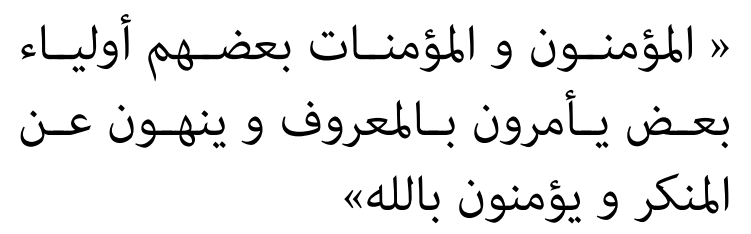

He is the Almighty means what he says where the knowledge of virtue and forbidding evil can only be achieved in the open society, which makes women contribute in turn to the side of men.

\section{Women Dakwah in Many Roles}

While it is noticeable that women's societies are not usually free from gossip and gossip, especially in occasions, weddings, etc., where there are many legitimate prohibitions, a significant question arises in the minds of many women. How can women advocate in these circumstances? Is it better to avoid the presence of such meetings and retire, or to have a role in changing these evils and enlighten women with the matters of religion and advised and guidance? After meditation, it is clear that what stands in front of the dowry sisters in the presence of some of these councils is essential:

First: the lack of forensic science, which helps them to face evil by arguments and legitimate evidence Second: modesty and fear of confrontation and a sense of inferiority prevents women calling to perform their mission in the matter of good and forbidding evil and advised others.
There may be a third reason despair and the belief that such meetings are useless and influential. In the face of these questions and reasons, Dr. Ibrahim Qassem shows that the role of women advocates is not limited to throwing words and denying evil in public occasions only, but can do advocacy work towards her relatives and friends and neighbors as much as possible, not limited to the category of another, although the relatives have a greater right because of kinship, Advocacy continues at the school, the occasion, the market, the hospital, etc. whenever necessary, and in each case use the method it deems appropriate.

On the other hand, the lack of presence of preachers for such occasions gives a greater opportunity for those who harbor the whims and deviations to spread their poison among ignorant women, and women often advocate the spread of some of these things as a result of their reluctance to attend these occasions and dare to speak, advice and guidance.

In fact, the presence of such events is a real opportunity for women who should not be neglected because they may not have such a number in one place. Women on these occasions contact and know a group of women who may not be able to reach or recognize them except on such occasions.

The majority of these types of women do not attend such meetings, but the meetings of the call and study and the councils of 
science are often absent from them, are not excited to attend, and some do not know about such councils, so these meetings were an opportunity to reach the hearts of women who They know nothing about the good councils.

The woman who is calling to think about the appropriate method of advocacy in such events, so that her speech is public and appropriate and away from details may raise unnecessary things, and to be keen on such occasions to speak in matters and general rules without subsystems.

As for the shame of some women from the call especially on such occasions, Islam denounces such a negative and shameful shame that is not returned to the owner of the fine, but perhaps returned to him evil, If you know and appreciate the value of the meaning of Islam and its lofty principles, and remember what God promised to him by his righteous worshipers calling him of the great reward on the Day of Resurrection, he called on it to get rid of this shameful shyness and push it to start the call with courage and courage.

And the role of women in the reform of society is what is called the Holy Quran, which sees good and forbidding evil is undoubtedly and not denied only Makaber. The gift of the Holy Prophet in social life is conclusive evidence that Muslim women were present alongside men and at all levels. Here I am compelled to shorten some of the evidence that shows the constant and continuous presence in the life of the Prophet and after him in the open ages, which represented the finest era throughout Islamic history.

The women were very attendance and continued to participate in the mosque at the time of the Messenger of Allah to learn and call to Islam. It was narrated that 'Abd-Allaah ibn' Abbaas said that a woman prayed behind the Prophet and she was one of the best people, and some of the people came forward to be in the first row so that they would not see them. Some of them were delayed until they were in the other row. ولقد " علمنا المستقدمين منكم و لقد علمنا المستأخرينه

Although there are people who like to get closer to women and to haunt their wives in one form or another, the Prophet did not change his mosque, but did not prevent women from the hall and did not erect the walls between the sexes, nor Isabel isolation buffer, believing that the issue issue of education and persuasion and not $A$ case of repression and intimidation, as it is today in many countries.

And with the fact that women went to the mosque to raise the jealousy of couples, no one dared to prevent the believers from the participation of believers the best prayers and collective good to listen to Friday sermons after he said $\gamma$ » تمنعوا إماء الله بيوت اللهه (البخاري، جمعة 948)

It was narrated that Omar ibn al-Khattab was arguing with his wife Autka, as she had many prayers in the mosque, and Omar used to say 
to her: "And Allah, you know that I do not like this," and she said, "I do not end until you finish me." : And Omar was stabbed while she was in the mosque »

The intransigent in this good treatment of women in the early Islamic ages finds that the prophetic desire to participate in the establishment of prayers, learning, education and the call to God is conclusive proof that women are not as people think today is awrah, and evil must be excluded from life.

\section{Women's Roles in Politics and Covenant}

Women were widely involved in various political engagements and were in themselves an invitation to reform society and reduce the political burdens of men. The Prophet I had opened Mecca after eight years of migration to the city, and had been sentenced before the death of some of the criminals of its people. When he returned to open Mecca, these criminals fled for fear of the rule of justice, but the son of Hbira had lived with the mother of Hani, the cousin of the Prophet Vajartha, some of the Companions objected to this era of femininity and protested the woes they tasted such as Ibn Hubira.

Then came Um Hanai to the Prophet I said: "O Messenger of Allah claimed my mother's son, her brother, Alia, that he fought men have conducted, he is the son of Hubira O Messenger of God, the Prophet said
This is the Prophet, I respect a covenant given by a woman to one of those wanted for justice, and never let her down. Is it considered those who say that women have no value in Islam and are many, and do they fear Allah and follow the guidance of the Holy Prophet.

\section{The Role of Women in Public Dialogue and Negotiations for Rights}

The positions of women in their dialogue and discussions of many matters of interest to the community, but the Prophet and the presence of men many are hardly any longer, and this raises the embarrassment for them to participate fully with men, and those positions include.

It was narrated that Muslim Ibn Ubayd said that Asma 'bint Yazeed al-Ansariyah came to the Prophet I and he sat among his companions.

She said: "My father, you and my mother, may Allah be pleased with you, I am the one who brought women to you. God sent you to all men and women. So, we protected you and your God.: Do not we share in this wage and good? Then the Prophet turned to his companions with his whole face and then said to them, "Have you ever heard a woman's article better than her question about her religion?"

\section{The Role of Women and Their Presence in Public Events}

The meetings of the two festivals were a mass of people coming from every direction and 
direction, and the Prophet himself supervised the activities of the Eid Festival, which was not only a hall as Muslims think today was a day of gymnasium, wrestling and dueling. The Prophet (peace and blessings of Allaah be upon him) commanded all Muslims to attend these days because of the good and communication between the members of the Muslim Ummah. One of the games that was organized during the days of the feast was playing Abyssinia with dances and bayonets, and Aisha was following these games with the Prophet I. Um Atiya al-Ansari said that the Prophet said on the day of Eid: "To come out of the girdles.

Thus, the Prophet I made the days of the two days an Islamic exhibition where Muslims meet all men and women, old people and children without discrimination, and even women menstruating the Prophet ordered them to go to the hall and if they do not pray. One of the women apologized to Prophet I that she does not have a jilabah. The Holy Prophet said to her: "To wear her from her jilbab, to witness the good and to invite the believers."

Is not this text a sign of inspiration for the Muslims to ease the burden on their women to participate in social life and religious and national events, Akonon change women from the Messenger of God when they claim that time has been corrupted and that people have changed?

\section{Women at Work}

The woman worked under the Messenger of Allah and earns money by herself, her husband and her children. This is Rita bint Abdullah al-Thaqfiyya, the wife of 'Abd Allah ibn Mas'ood, who was a prostitute who worked and acted on her husband and her children. She came to the Prophet and said to him, "I am a woman of workmanship. I sell, not to my parents, and my husband has no money. They ask me about charity. Do they have a reward? "The Messenger of Allaah (peace and blessings of Allaah be upon him) said to her.

And there was a woman in the city called Hula perfume, was the Prophet Yans and visit them. She used to sell perfumery. If he entered his house, he said, "Where is alHula '? I find the wind of perfumery. Have you swallowed anything from it today? "

The irony is that there are many men today who claim to have the right to guard women and do not work, and do not leave their wives working under the pretext that women's natural place is home. Note that many of these wives enjoy high certificates that enable them to benefit the community and thus provide the best example of women working and productive, which is the best successor to the good predecessor as evidenced by the effects we have provided.

\section{Women's Role in Medicine and Fighting}

The Muslim women were the days of the Prophet and in the era 
of the Rashidi fighting alongside the man with all severity and strength. Spring was the daughter of a refuge was invading with the Prophet Vdai wounded. And Safia bint Abdul Muttalib saw the day of the trench Jewish men spying on the city and hit him with a column and killed him alone. And the mother of alAla Ansari was treating the sick companions, and was treated Osman bin Mazzoun until he died. As for Rafidah al-Islamiyya, it happened, and the Prophet did not have a hurdle. It was to treat the wounded after the battle of the trench, and Dawat Saad bin Mu'adh.

\section{The Role Of Women In Prostration And Recitation}

Troy Fkihp diligent Aisyah ra, saying: «entered the Prophet and I have two singers sing singing Ba'ath, and lay on the bed and around the face and entered $\mathrm{Abu}$ Bakr Vantharni, and said the devil's mumzerah when the Messenger of God? Then the Prophet accepted him and said: Let them, says Aisha, when he forgot their muffled and went out »

In another narration, the Prophet said to Abu Bakr: "O Abu Bakr, every nation has a festival and this is our festival." In another narration, Aisha says: "I have two neighbors who are beating and beating." The hadeeth that mentions singing and beating the daff in front of the Prophet repeats more than two Ten times in Bukhari and Muslim and more than once in the nine books, and Ibn Hajar al-Asqalani mentioned in his book Injury and translated to it as «the pigeon of the singer».

Despite these frequent texts in the semantics of the Hadith, the fuqaha 'continued to pursue all the obligatory singing of committed women, as if they were shame and unthinkable. And thus closed the door in the face of committed singing, which gave way to the falling singing, which does not care about virtues or values, these militants provided a great service to the disobedience and immorality because they prepared a strong competitor was able to turn the scales and fill a void filled obscene and obscene.

But the people of their people hardened even denied Islamic songs, as if Islam came only for the funeral and condolences. All this is without establishing a weight for the said hadiths, which are texts in its field.

And Imam Ibn Hazm addressed the ancient to those who deny the modest singing committed in his great local book, and proved by his knowledge and his critical and bold tone that there is no single talk is reliable in the prohibition.

And it is true that the Prophet was urging Muslims to play innocent and say: "O Aisha, is it with you. And he said in a wedding: «Have you brought with her a slave striking, the women of Ansar admire the fun. Bdf and sing? »

Finally, the participation of women in advocacy was the result of their continuous presence in all 
areas of life, and succeeded in that a remarkable success until history has the positions of advocacy of the finest.

\section{Conclusion}

The call to Allah is one of the greatest things that a woman must take care of and care for, especially in this age when the strife overwhelmed and exceeded the limit and many people moved away from the right religion and opened to the West, including deviations and corruption in the doctrine and ethics and values and others.

In our meeting with him, Professor Ibrahim Mohammed Qassem (professor at girls' colleges in Dammam) tells us that the role of women in advocacy is a great and worthy role for Muslim women to take care of and care for. Women know and know women's gender identities. Their effect is more beneficial than men if the means used are used.

And then the area of advocacy for her welcomed and extensive that the presence with the daughters of their sex and mixing directly with them no doubt that facilitates the process of advocacy and give them a kind of love and brotherhood, so it was necessary for Muslim women not to despise themselves and do not miss such opportunities.

The woman who is calling to think about the appropriate method of advocacy in such events, so that her speech is public and appropriate and away from details may raise unnecessary things, and to be keen on such occasions to speak in general matters and rules without subsystems.

As for the shyness of some women from calling, especially on such occasions, Islam denounces such a negative and reprehensible shame that is not good to the owner, but may be returned to him with evil. If the woman knew and felt the value of the meanings of Islam and its supreme principles, The righteous worshipers who call him from the great reward on the Day of Resurrection called it to get rid of this shameful shyness, and pushed it to start the call with boldness and courage.

\section{References}

Ahmed Ajayev, (2012), Women's Rights in Islam, Hendawi Foundation for Education and Culture

Ibn Atsir Asad al Ghobah, Juz 8

Ibu Hajar Al Atsqalani, Fath Al Bari Part 7

Bukhari book force the five, the door of safety of women and their neighbors,

Bukhari, the Book of the Two Days,

Bukhari the story of Umm
Salamah with her folk,
expenses 4984, and also
the story of Hind bint
Atab.

Bukhari virtues of the companions, the door of the Prophet of the Prophet on the city. 
Tirmidhi interpretation of the modern stone classified Abdul Razzaq Part3

Yasmine Gamal Abdel Wassa Wadf, 2012, Women's Rights in Islamic Law and Positive Law, University of Science and Technology, Republic of Yemen 